\title{
23 CONSTRUCTING The Scientific Aesthetics of Architecture in France 1860-1900
}

\section{Estelle Thibault}

How is it conceivable that architectural forms are able to elicit an emotion or express a mood? How can architecture, which uses non-imitative forms, represent ideas and convey specific feelings to the observer? These concerns that so famously begin Heinrich Wölfflin's Prolegomena zu einer Psychologie der Architektur (1886) also pervade French writings of the period. ${ }^{1}$ The notion that architectural forms can have emotional implications, and an influence on feelings, is a truism that has long confronted architects. Character theory, after all, emerged in France over a century earlier, and attempted to establish a universal language of architecture based on the codification of emotions. Julien David Le Roy, Nicolas Le Camus de Mézières, and Étienne Louis Boullée considered that the talent of the architect consisted of judiciously organizing the effects that buildings produce and the sensations they prompt. But on what theoretical framework could this skill be based? The capacity to produce emotional effects was generally attributed to the intuitive faculties of the artist, to his imagination and genius, and only very gradually did it find its theoretical foundations. This rationalization of architecture's means of expression was developed during the nineteenth century, against a backdrop where aesthetics was gradually developed as a scientific discipline supported by several fields, from the philosophy of art to the sciences of perception. ${ }^{2}$ In this development, the richness of the Germanic context is well known. The theories of empathy and of expression, as well as the development of knowledge on perceptive phenomena, were found to be particularly fertile for the burgeoning conceptions of form and space. ${ }^{3}$ In France, however, aesthetics was established as a discipline exceptionally late, despite a relatively early attention to architecture's mode of expression. The belated process by which aesthetics acquired official recognition in France stands in sharp contrast to the German situation, where it became a discipline in its own right and was taught at universities by the end of the eighteenth century. ${ }^{4}$ 


\section{Psychology, Aesthetic, and Ornament}

But before the official acceptance of aesthetics as a science capable of assisting artistic creation, French architects combined philological, physiognomic, and philosophical research into idiosyncratic theories of expression, some loosely based on the work of the pioneering German aesthetician, Alexander Gottlieb Baumgarten. It was only in the nineteenth century that French aesthetics began to take form in a domain of autonomous knowledge, with its own objects of study and methods. Indecisiveness regarding the appropriate terminology ("science of beauty," "philosophy of art," "science of art," and "aesthetics") were symptomatic of the difficulty, during a period of great reconstruction of the fields of knowledge, in situating aesthetics between philosophy and the social or experimental sciences. ${ }^{5}$ The establishment of this scientific identity was accompanied by the appropriation of an institutional position that was a similarly laborious process, since the specifically philosophical discourse on beauty had difficulty finding its place. In 1826, for instance, the philosopher Théodore Jouffroy presented theories that were considered to be foundational for modern French aesthetics in a series of lectures given outside an institutional setting. ${ }^{6}$ The process that led to a recognition of the discipline began in 1857, when the philosophy department of the Académie des Sciences Morales et Politiques launched a competition for the definition of a French version of a "science of beauty" that was to be distinct from German examples. The works arising from this competition questioned the boundaries of philosophical reflections on art. In positivist circles, the term "aesthetics" also designated a modernized approach - historical, sociological, or psychophysiological - to art. $^{7}$

Revitalized by this initiative, the 1860s were a particularly propitious period for exchanges with architecture. A number of critics and academics proposed to apply the new science of aesthetics to artistic practice. This was the case at the École des Beaux-Arts, where the first chair of "aesthetics" in France was set up in 1863 and entrusted to the architect Eugène-Emmanuel Viollet-le-Duc, before being taken over by Hippolyte Taine. At the Collège de France, the first incumbents of the chair of aesthetics, a chair established in 1878, defended the idea of a "practical" approach, and together they provided artists and art enthusiasts with general criteria evaluating artistic works. The psycho-physician Charles Henry's Introduction à une esthétique scientifique of 1885 , which had tremendous impact on postimpressionist painters, marked the peak of the popular interest in a scientific approach guiding artistic practice. ${ }^{8}$

Out of this uncertain landscape arose a demand for a scientific aesthetics of architecture, that is to say, for a theoretical framework that could provide a rationalization of the means of expression. The will to construct a science of architectural aesthetics could thus be considered as one of the facets of the rationalist project of the nineteenth century. The impulse to establish a scientific approach to the structural and utilitarian demands of architectural practice gave birth to a new ambition: to scientifically determine and produce architectural design and formal configurations. 


\section{A Grammar of Expression}

The establishment of an emotive architectural language was first attempted by the historian and art critic Charles Blanc in Grammaire des arts du dessin, published in 1867. This work was the first to unite the theory of architecture with aesthetics. The pages that deal with architecture were written at the same time as Science $d u$ beau by the philosopher Charles Lévêque, winner of the Académie's competition on the definition of French aesthetics. ${ }^{9}$ Blanc's important contribution to this "thoroughly modern science" that was destined to "bring light to the teaching of the arts" became more pronounced in 1878, when he became the first to occupy the chair of aesthetics at the Collège de France. ${ }^{10}$ There are numerous affinities between the Grammaire and Science $d u$ beau, such as their definition of beauty and the architectural examples they chose to analyse; these indicate a shared taste for the classical French tradition and for Greek antiquity. The problematics of ideal beauty and the affirmation of the moral value of art demonstrate Blanc's adherence to Spiritualism which, at this time, dominated the official institutions of French philosophy. Reflecting on psychological effects and the essence of beauty, Lévêque proposed an introspective analysis of the feelings experienced while viewing artistic works based on the theories of Victor Cousin and Théodore Jouffroy. This method, which was termed "psychological," oscillated between speculation on principles and self-observation. It was applied to Greek architecture at the École française d'Athènes during Lévêque's time there as one of its first members. The philosopher went as far as to evoke explicitly the possibility of a "psychology of architecture."11 In the pages of Science du beau, Lévêque described the strong impact that he felt on the site of the Acropolis in the company of architects and archaeologists occupied in drawing the ancient ruins. Likewise, the chapter on architecture in Blanc's Grammaire des arts $d u$ dessin, published upon his return from Greece, recounts a similar experience in which the Parthenon served as a model and inspiration. The approach was spiritualist, psychological, and somewhat a-historical, neglecting the context of the works in order to give priority to formal analysis and the establishment of ideal standards.

Compared to Science du beau which was addressed to philosophers, the Grammaire was aimed at a broader public of art enthusiasts and artists. Like a manual of grammatical rules, it was an instructional handbook intended to popularize the basic principles of artistic taste. By drawing an analogy between art and language, Blanc sought to assemble and establish a suitable vocabulary for an inventory of the means of expression specific to the arts of drawing. Expression, in this context, suggested the exteriorization of ideas and feelings in order to communicate them to the spectator through a system of natural, non-imitative signs. This metaphor of art as an immediate emotional language was already present in Essai sur les signes inconditionnels dans l'art (1827-32) by David Pierre Giottino Humbert de Superville, whose littleknown theses were propagated by Blanc in the Grammaire, and thus made a strong impression on artistic circles at the end of the nineteenth century. ${ }^{12}$ It should be 
remembered that, from the very start, the Essai formulated an approach to expression that was close to that of German Romanticism. Humbert's "unconditional signs" also bore some similarities with the "symbols" evoked in Théodore Jouffroy's lessons on aesthetics. ${ }^{13}$ These notions conveyed an empathetic conception according to which geometrical figures as well as sounds and colors have in themselves, independently of what they represent, the power to transmit an emotional charge. It was supposed that there existed in nature a language of immediately comprehensible forms.

Having assimilated these conceptions, the Grammaire proposed a program to rationalize the effects of architecture. Blanc identified a set of formal mechanisms the significance of which was deduced from the observation of nature. To produce the feeling of the sublime, for instance, the architect needed to proceed by analogy and borrow formal elements from the most impressive landscapes. The theme was certainly not new, since precipitous cliffs, limitless plains, and impenetrable forests had been seen as sources of powerful effects in architectural writings of the eighteenth century. But the Grammaire distinguished itself from empirical stylization in precisely identifying the dimensional or geometrical criteria which produced these feelings: size, simplicity, and the predominance of lines as well as the scale, the treatment of the surfaces, light, and the relationship between solids and voids. These formal configurations were then extracted from their natural origin to be organized into a system. This process of abstraction, in the literal meaning of the term, is easily seen in the linear signs deduced from the human face in an illustration that Blanc directly borrowed from Humbert de Superville. The effective values of the three types of line - ascending, horizontal, and descending - are submitted to three simplified figures which indicate their sentimental value (Figure 23.1). The importance of Humbert de Superville's original illustration in the development of an approach to abstraction has often been emphasized. ${ }^{14}$ Architecture had a special place in this new approach to form, for the unconditional effects of linear signs was first illustrated by buildings: for instance, the expansive lines of a Chinese pagoda, the melancholic curvatures of a Gothic cathedral, and the tranquil horizontals of a Greek temple (Figure 23.2). In Blanc and Humbert de Superville's recognition of architecture's ability to affect the senses in a forceful way without having recourse to imitation, one can see the underpinnings of a theory of non-figurative art.

Charles Blanc's discussion of facial lines in his Grammaire was a special reference to the classical tradition of deriving the standards of beauty and expression from the human face. Blanc borrowed heavily from Quatremère de Quincy's essay on "Character," in which the architect is invited to find in the human body the principles of his art and to transfer the classical notions of proportion, harmony, and character to buildings. ${ }^{15}$ According to Jouffroy and Humbert de Superville, facial expressions were particularly effective natural symbols and could arouse immediate sympathy. Blanc's "linear signs" follow this tradition of anthropomorphism linked to physiognomic theories of expression, while opening the way to a more 


\section{TABLEAU SYNOPTIQUE}

DES DEVELOPPEMENTS DU FAIT PRINCIPE, AMBNANT LA VALEUR INCONDITIONNELLE ET IDENTIQUE DES SIGNES LINEAIRES ET COLORÉS.

Fait-physiologique, dans ses trois grandes variétés au maximum moral.
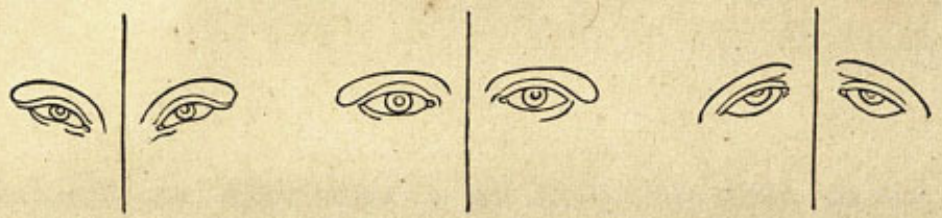

Eléments ou Directions linéaires des trois grandes variétés de la face humaine, dans leur rapport à l'Axe, comme expression de l'homme organique, intellectuel et moral.
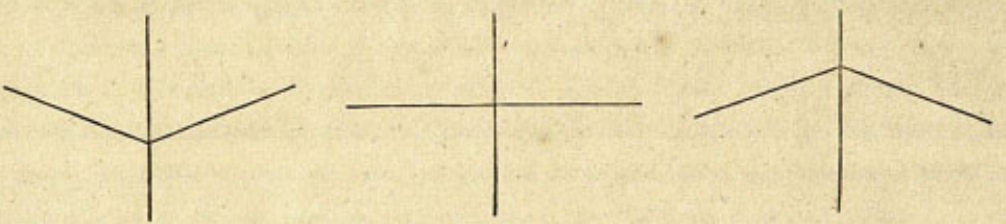

Valeur et Analogies de ces trois différentes directions élémentaires.

Exparsives. sacillatiou, agitation. dispersiou. caplosion, édact. couleur Rouge.
Sorizoutale. équilibre, colue. ordre. clacté, Punière. couleur Ulaucbe.
Couvergentes. concentration, recueillement. soleunité. profoudenr, ténèbres. couleur DGoire.

Identité de ces analogies pour chaque série, dans la réunion de leurs deux termes extrémes, embrassant les termes moyens, d'où pour ces six expressions leur valeur d'

$$
\text { Gxiomes, }
$$

ou Eléments dinterprétation et de démonstration sentimentale de toutes nos perceptions visibles.
expousives.
Bocizoutale.
Blounc.
convergentes.
nove.

couge.

Figure 23.1 D. P. G. Humbert de Superville, "Synoptic Table," from Essai sur les signes inconditionnels dans l'art, I, 24. 

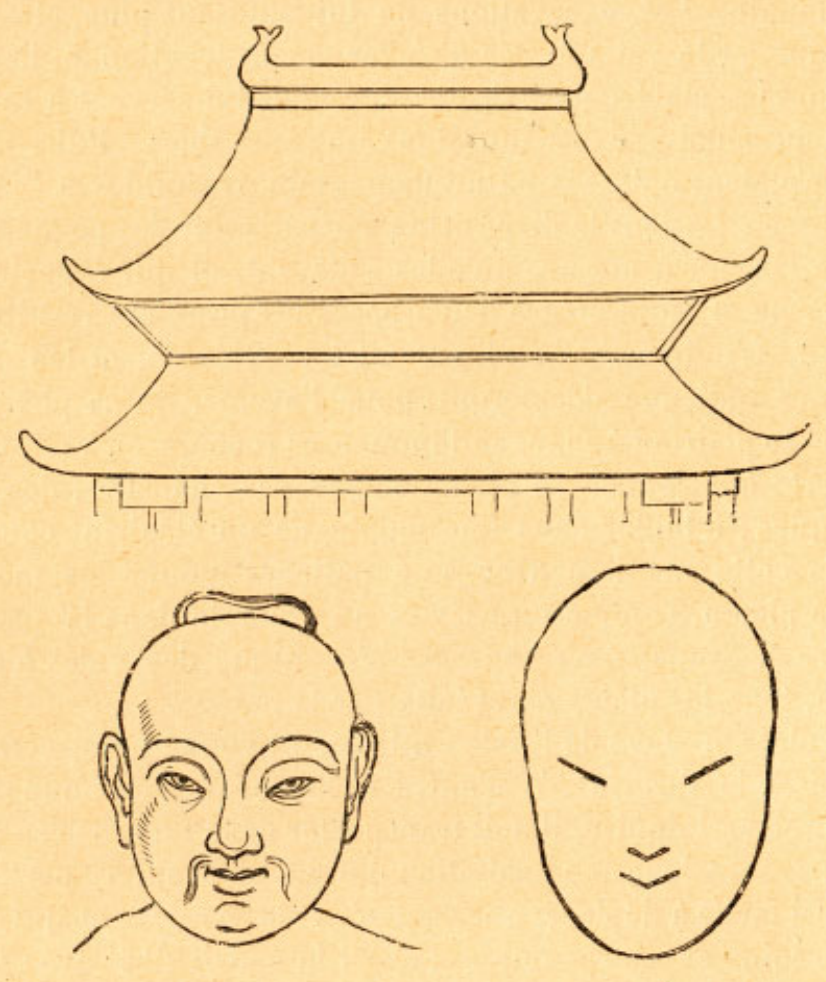

Figure 23.2 C. Blanc, "Architecture's Relation with the Human Face," from Grammaire des arts du dessin, 2nd ed. (Paris: H. Laurens, 1880), 108.

abstract and geometrical approach. The subsequent success of these ideas was undoubtedly linked to their ambiguity. They permitted an expressive and nonimitative approach to an architecture that was faithful to a classical tradition in which the body was the paragon of ideal beauty, while at the same time developing a new analysis of architecture as a composition of lines.

\section{Sympathy and Influence: A Psychology of Architecture}

In the second half of the nineteenth century, the idea that architecture had a psychological influence was substantiated in the first French theories of empathy. ${ }^{16}$ The term "sympathy," which in the eighteenth century had designated the capacity of a subject to feel the sentiments displayed by others, found its real aesthetic meaning when Théodore Jouffroy applied it to non-anthropomorphic objects, making it the basis of an expressive faculty that sought other means than the arousal of compassion by the representation of features directly expressing emotion. Defined as the exchange of psychological states, sympathy appeared 


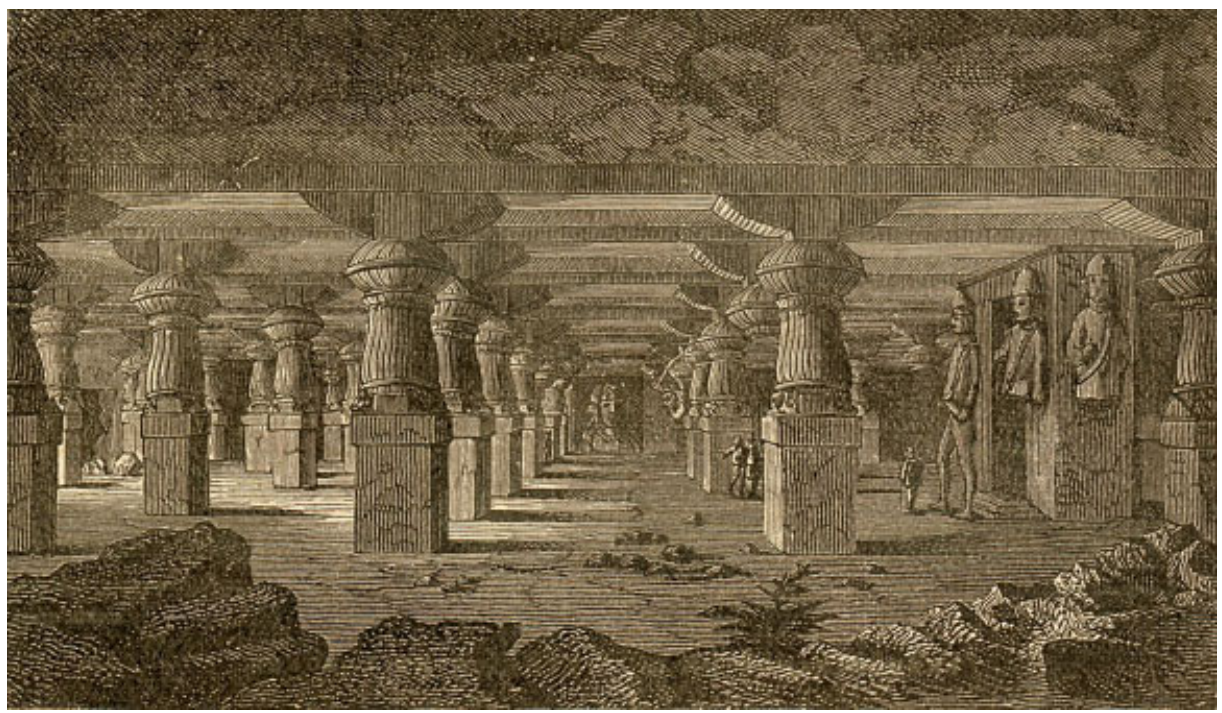

Figure 23.3 C. Blanc, "The Predominance of Depth," from Grammaire des arts du dessin, 2nd ed. (Paris: H. Laurens, 1880), 89.

as a precursor of the German theories of Einfühlung developed in the following decades. The French architectural discourse prefigured certain themes, emphasizing the feelings transmitted by the configuration of space and by the arrangement of matter. Charles Blanc thus associated the three dimensions of height, depth, and breadth with the capacity to arouse, respectively, feelings of elevation, stability, and mystery (Figure 23.3). Furthermore, Blanc described the different moods felt under vaults of different shapes and modulated by different qualities of light. ${ }^{17}$ This psychological approach to space was accompanied by an empathetic reading of matter. Following Jouffroy's expansion of the expressive faculty to include all objects possessing an internal "force," it became possible to consider the emotive power of architecture. For Charles Lévêque, therefore, the physical resistance inherent in materials was presumed to be the originator of the "expressive energies" of architecture. ${ }^{18}$ By tapping into "the characters and signs of the inorganic resistant force," by using "the ideal forms of geometrical solidity" (cube, parallelepiped, pyramid, cylinder, and cone), and by directly representing power and mass, architecture was able to express what Lévêque termed the "universal soul." In the section that Charles Blanc devoted to the classical orders of architecture, the expressivity of matter supplanted the traditional communicative power of Doric, Ionic, and Corinthian columns. In contrast to the anthropomorphic interpretation of the orders, columns, for Blanc, poetically animated inert matter and dramatized what was otherwise an invisible play of forces, loads, tensions, and compressions. Ornamental details were read as "bold fictions" representing a feigned "artificial organism" with "soft substances mixed with rigid 


\section{Psychology, Aesthetic, and Ornament}

bodies and elastic materials pressed by heavy matter."19 Through this expression of internal forces, whether real or simulated, the architect's goal was to animate the column. This concept permitted a different humanization of the three classical orders. Architecture could convey power or grace according to the way it expressed resistance of materials. The classical vocabulary gained a renewed sense of legitimacy in these interpretations that united poetic expression with physical and material strength.

Other commentators considered optical processes. In his Philosophie de l'architecture en Grèce, Émile Boutmy presented the Parthenon as a mechanism that organized the visual sensations of the observer. ${ }^{20}$ His description of the building followed the motion of the eye moving over it. The fluting "unerringly directs the gaze along the marble," "guiding it as though on unbending rails towards the entablature." The monument structures the movement of the eye, regulating its speed and acceleration. The column capital "pushes the eye forward," the architrave evokes "a hiatus ..., a moment of respite and replenishment, the time to take one's breath, ... a peaceful passage" where the eye, having rested for a few seconds, can enter, "refreshed and awakened for the grand heroic museum that awaits."21 In 1897, Theodor Lipps proposed similar descriptions in which the movement of the eye, in reproducing the lines of the column, participated in the psychological identification process of the Einfuihlung. ${ }^{22}$

These interpretations suggested a strong interaction between the subject and its natural or built environment. The principle of a reciprocal adaptation, a deep sympathy between landscapes, civilizations, and artistic and industrial products, gained prominence (Figure 23.4). A very literal interpretation of this idea was proposed by the architect Henry Espérandieu when he emphasized similarities between the geography inhabited by a people and their racial characteristics, dress, and architecture. ${ }^{23}$ In a more subtle way, the commentators of the Acropolis emphasized the symbiosis of Greek architecture with its human and natural context, emphasizing the profound physiognomy of the landscape with which the soul of the artist was necessarily imbued. Boutmy's Philosophie de l'architecture en Grèce identified the factors which he considered to have determined the particularly acute sensitivity of the Greek architect. ${ }^{24}$ The luminosity of the sky, the purity of line, and the clarity of the contours of the landscape provided the Greek with a "particular standard of taste" distinct from that of northern peoples born under a misty sky. ${ }^{25}$ The thesis that the surrounding landscape is a generator of optical habits became an argument promoting the necessary harmony of architecture and its environment. Such reasoning, which recognized the influence of the environment on collective mentalities, also had a political and social vector. ${ }^{26}$ Émile Boutmy explicitly proposed the project of a "psychology of architecture" inspired by Hippolyte Taine and anchored both in the psychology of the subject and in a history of civilizations. This approach was intended to understand the influence of environment on society and to "frame all the questions of history in a general psychology of time and of race." 27 

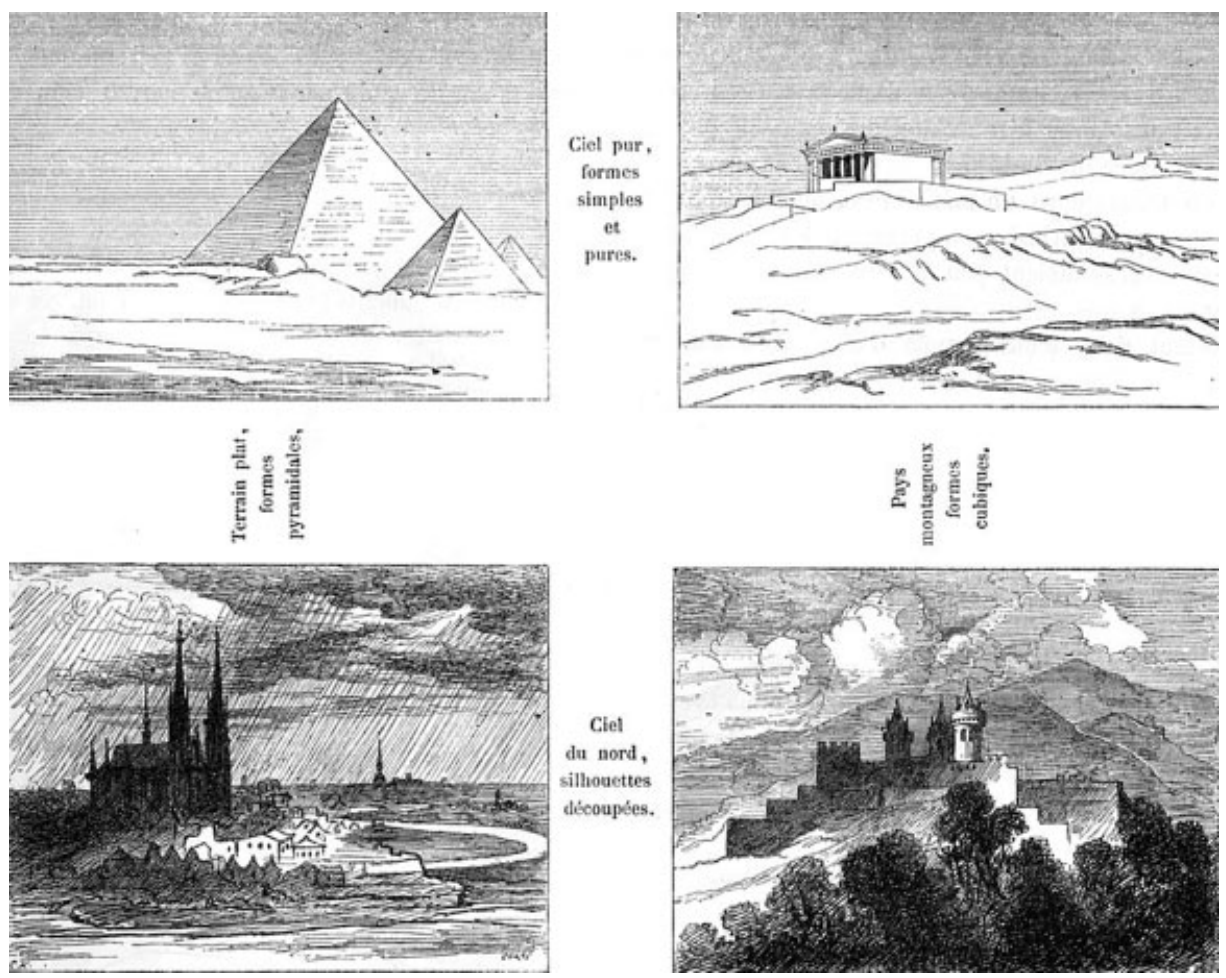

Figure 23.4 Henry Espérandieu, "The Sentiment of Architecture," from Revue générale de l'architecture et des travaux publics 29 (1872): col. 14.

\section{A Positive Aesthetic at the Service of Social Sentiment}

The Revue générale de l'architecture et des travaux publics (RGATP) was another forum of debate on the definition of an aesthetic science applied to architecture. The $1860 \mathrm{~s}$ witnessed a renewal of the concern for architectural expression, a question that had been given a prominent place in the pages of the journal over two decades earlier by César Daly, its founder and director. The hypothesis of a "science of sentiment" had its roots in Fourierist and Saint-Simonian circles. Around 1830, it was already a key element of an approach to social art founded on mechanisms of psychological response. ${ }^{28}$ The public competition for the design of a monument at the Bastille in commemoration of the Revolution of July 1830 proved to be an important opportunity for experimentation. For a monument so charged with social significance, it was appropriate to use a language "of immense variety, comprehensible in all centuries and for all peoples," 29 a more universal semantics than the conventional vocabulary of architectural orders. The review of the projects essentially revolved around the relevance of the figurative symbols used, which Daly examined as 
though the projects constituted an open book abounding with associations of ideas. Daly's approach, based on the intuitive exploration of semantic correspondences and on direct analogies between the "physical and moral worlds" and "the domain of symbolism in art," unmistakably brings to mind Charles Fourier's approach, which conceived of such an analogy as a "fixed science" capable of decoding social laws inscribed in a universal cosmogony. In the late 1840s, Daly nevertheless dropped the figurative signs of ornamental iconography in favor of a more sweeping and abstract symbolic register, that of the geometry of buildings. From this period on, shape and form, and not figurative representation, became the central vehicle for architectural expression; geometry, Daly would write, "makes its symbols available to architecture." ${ }^{\prime 30}$ One could readily ask to what extent this refocusing on the expressive value of forms might be indebted to Théodore Jouffroy's Cours d'esthétique (1843), published in the same period. Daly also seems to extend this reflection toward the art of building, taking lines to be the most effective vectors of expression. This movement toward abstraction accompanied the rise of another thesis inspired by Fourierist artistic criticism, that of a correlation between aesthetic and social forms. The various architectural styles, reduced to their principal geometrical characteristics, were thus considered as the symbolic reflection "of the material, moral and intellectual state of humanity in the various periods of its development." ${ }^{\prime 31}$

There were new developments on the means of expression peculiar to the art of building in the 1860s, when Daly reasserted the primacy of sentiment. Aesthetics, "a new science under construction,"32 was identified as a precious ally to counter the debasement of architecture to a utilitarian or technical function at the moment when Daly was taking his distance from the excessively strict rationalist tendencies advocated by Émile Trélat at the École Spéciale d'Architecture. ${ }^{33}$ Although it coincided with the debates on the science of beauty, Daly's interest in aesthetics nevertheless took its models from Auguste Comte's Positivism rather than Spiritualist philosophy. He was also motivated by the reforms of the École des Beaux-Arts in 1863 which created a course in the history of art and aesthetics taught by Viollet-leDuc. Alongside history, aesthetics could appear to be a modern substitute for the antiquated courses on architectural "theory." The status of the three disciplines history, theory, and aesthetics - and their limits and interactions, were called into question. From this time forward, the RGATP became a kind of think tank that operated outside the academic system and developed new ways in which aesthetics could be introduced into the architectural curriculum. Many articles shared Daly's aim of using historical analysis to interpret the styles of the past in such a way as to discern the forms of the future. The same underlying motivation can be seen in Daly's typological studies on, for example, funerary architecture, and in his critical articles on contemporary buildings such as the Palais du Trocadéro. Developed over a considerable period, these reflections concluded in the late 1880 s with the creation of a "scientific aesthetic of architecture" based on the positive sciences. Its division into two branches reflects the inherent complexity of architecture 
governed by both relative and universal laws. On the one hand, the historical sciences, owing much to a Saint-Simonian world view, approached the principle of the variability of taste according to civilization. They tended to read the styles-types as the embodiment of a constructive principle in a form that exteriorized the collective sentiment peculiar to each society. On the other hand, the so-called exact sciences allowed the treatment of the "constant laws," that is to say, the "aesthetic and symbolic properties of forms" thought to be invariable because they were linked to the mechanisms of perception. ${ }^{34}$

\section{Architecture and the Sciences of Perception}

The appeal of the exact sciences is an indication of the interest, in the second half of the century, in the physiological approaches to perception in the RGATP and other architectural publications. Mathematical aesthetics, based from that moment forward on arguments linked to sensorial physiology, was the first approach. It was promoted by engineers from the École polytechnique, such as Auguste Aurès and Édouard Lagout, author of an "Equation of Beauty" that guaranteed "pleasant sensations." 35 The neo-Pythagorean hypothesis of a mathematical formula of beauty was now validated by new knowledge of the sensorial organs. According to an interpretation that grew in influence toward the end of the century, the physiology of perception reinforced the idea of a harmony governed by mathematical laws which, if mastered, would provide a fuller grasp of the social sphere. Designated by Daly as an auxiliary science useful for the architect, "aesthetic optics" covered a wide range of new research on vision, the most notable being that of the chemist Michel Eugène Chevreul. The position taken in favor of architectural polychromy undoubtedly increased the interest in this work. The law of the simultaneous contrast of colors, set forth by Chevreul in 1839, long remained a model contribution of science to artistic practice. While being resolutely non-philosophical in approach, Chevreul's work demonstrated that laboratory work could result in the formulation of concrete rules that were directly applicable to industrial and artistic production. More generally, architectural discourse reflected the profound interest in new theories of optics and acoustics applied to the fine arts, starting with the translation, in the second half of the 1860s, of the works of Ernst Brücke and Hermann von Helmholtz. Optical physiology also allowed for a return to the phenomena of optical correction that had been commented on at length in relation to ancient Greek architecture. Though Auguste Choisy, in his Histoire de l'architecture, ${ }^{36}$ drew attention to the optical corrections used by the architects of the Parthenon, Émile Burnouf, a former resident of the École française d'Athènes, had already described these "errors of influence" in $1875 .{ }^{37}$ From then on, optics was seen as the part of aesthetic science that gave the architect the necessary mastery over the differences between reality and perception in the design of his buildings. 
The psycho-physiological leanings of aesthetics became stronger in the final decades of the century. A wide range of approaches such as new and experimental methods for measuring sensation, inventive research on hypnosis and suggestion, the creation of social psychology, and the debates on evolution and the life instinct paved the way for a rethinking of the function of art, its action on the individual, and its social role. ${ }^{38}$ As of 1876 , the Revue philosophique de la France et de l'étranger provided a platform for this scientific discourse on the perception of works of art which, following the terms set forth by the German experimental psychologist Gustav Fechner, promoted an "aesthetics from below" based on the study of sensorial phenomena. In these works, the reevaluation of sensation was accompanied by a new emphasis on movement, which was given a central place in the aesthetic process. This dynamic conception of perception gave rise to a set of terms associated with movement: vibration, emotion, gesture, trajectory, and rhythm. In the Gazette des Beaux-arts, Georges Guéroult defended a "cinematic theory" according to which the essential mission of the fine arts was to stimulate the internal vitality of the observer and to mobilize his affective mechanism. ${ }^{39}$ This understanding of perception also modified the way that architecture was analysed in aesthetic works written toward the end of the century. To the physiological definitions of emotion, which were linked to luminous vibration or eye movement, were added empathetic conceptions in which the body played a different role. The philosopher Paul Souriau's Esthétique du mouvement (1889) is a good example of the prevailing tendency of identifying bodily and intimate experience with gravitational forces and pressures. ${ }^{40}$ Souriau noted that our perception of architecture cannot be reduced to a simple set of abstract lines. The observer's own body is forever caught up in the way we perceive the material nature of buildings and the internal stresses and balancing forces at work. These theories of perception formed new paradigms, leading to a redefinition of the spatial environment's means of expression. At the end of the century, the new knowledge of psycho-physiological reactions was also used in an attempt to monitor collective mentalities. ${ }^{41}$ For such authors as JeanMarie Guyau, the theories of influence which were already appearing around the middle of the century took the form of an aesthetic of crowds. ${ }^{42}$ Behind the ideals of sympathy, harmony, and suggestion, lay the dream of an art with unifying virtues and the potential for authoritarian misuse. The discipline of architecture would be profoundly transformed with the recognition of the architect's ability to shape behavior through the design of sensorial environments, a realization that would propel the architect into more acutely political territory than ever before.

Behind scientific aesthetics, the theoreticians of architecture gave rise to an expanding horizon, combining theories of expression, social psychology, and sensorial physiology with the aim of better defining the emotional reactions of the observer in front of a building. Between scientific exploration and theoretical fiction these fields aided in the codification of the visual language of architecture and the reduction of its forms to an abstract set of components with affective significance. This formalist reflection was compared to old stylistic categories while 
stimulating speculation on the architecture of the future. The notion of a scientific aesthetics applied to architecture was extended in the following century, in the academic culture of the École des Beaux-Arts and in modernism. This was attested by the "science of artistic composition" through which Gustave Umbdenstock, professor of architecture at the École des Beaux-Arts and the École Polytechnique, hoped to seize the "suggestive effects" of a historicist and regionalist architecture, as well as by the "physiology of sensations" that formed the basis for the sensorial economy of Le Corbusier.

\section{Notes}

1. Heinrich Wölfflin, Prolegomena zu einer Psychologie der Architektur (Munich: Kgl. Hof- \& Universitäts-Buchdrückerei, 1886).

2. Estelle Thibault, La géométrie des émotions: Les esthétiques scientifiques de l'architecture en France, 1860-1950 (Wavre: Mardaga, 2010).

3. Harry Francis Mallgrave and Eleftherios Ikonomou, Empathy, Form and Space: Problems in German Aesthetics, 1873-1893 (Santa Monica: Getty Research Institute, 1994).

4. It was not until 1928 that a chair of aesthetics was established at the Sorbonne.

5. Élisabeth Décultot, ed., Revue de métaphysique et de morale: "Esthétique." Histoire d'un transfert franco allemand, vol. 2 (Paris: Presses universitaires de France, 2002).

6. The École normale supérieure, where Théodore Jouffroy taught, was closed due to tight censorship under the restoration monarchy of Charles X. His Cours d'esthétique was published posthumously in 1843 .

7. In Système de politique positive (1848), Auguste Comte devoted a chapter to "the aesthetic aptitude of positivism."

8. Pascal Rousseau, "Un langage universel: L'esthétique scientifique aux origines de l'abstraction," in Aux origines de l'abstraction 1800-1914, ed. Serg Lemoine and Pascal Rousseau, 19-33 (Paris: RMN, 2003).

9. Charles Lévêque, La science du beau étudiée dans ses principes, dans ses applications et son histoire, 2 vols. (Paris: Durand, 1861, 2nd ed. 1872). The chapters of the Grammaire des arts $d u$ dessin were first published as articles between April 1860 and December 1866.

10. Charles Blanc, Grammaire des arts du dessin (Paris: École nationale supérieure des beauxarts, 2000 [1st ed. Paris: J. Renouard, 1867]), 623-4.

11. Lévêque, La science du beau (2nd ed., 1872), 2, 29.

12. Barbara Maria Stafford, Symbol and Myth: Humbert de Superville's Essay on Absolute Signs in Art (Cranbury: University of Delaware Press, 1979).

13. Théodore Jouffroy, Cours d'esthétique (Paris: Hachette, 1843).

14. Claire Barbillon, "L'esthétique pratique de Charles Blanc," in Charles Blanc, Grammaire des arts $d u$ dessin, 15-33 (Paris: Ensba, 2000).

15. Blanc, Grammaire des arts du dessin, 121.

16. David van Zanten, Designing Paris: The Architecture of Duban, Labrouste, Duc and Vaudoyer (Cambridge, MA, and London: MIT Press, 1987), 177-223.

17. Blanc, Grammaire des arts du dessin, 252-3. 


\section{Psychology, Aesthetic, and Ornament}

18. Lévêque, La science du beau (2nd ed., 1872), 2, 20-32.

19. Blanc, Grammaire des arts du dessin, 154.

20. Émile Boutmy, Philosophie de l'architecture en Grèce (Paris: Germer Baillière, 1870).

21. Ibid., 182-3.

22. Theodor Lipps, Raumaesthetik und geometrisch-optische Taüschungen (Leipzig: J. A. Barth, 1897).

23. Henry Espérandieu, "Le sentiment et l'architecture: De la forme et de la coloration des édifices," Revue générale de l'architecture et des travaux publics 29 (1872): cols. 12-18, 51-5, 107-10.

24. Émile Boutmy taught history at the École spéciale d'architecture from 1865.

25. Boutmy, Philosophie de l'architecture en Grèce, 94.

26. Humbert de Superville's Essai already demonstrated an acute consciousness of the influence of the built environment. Before the evolutionist hypothesis of an action of the environment on man was formulated, he posed the question whether the town is the "new nature," thereby perceptibly changing the psychology of the subject: "Architecture, seen in its true light, is, in the present state of society, almost the only environment of town-dwellers, and the language in which it addresses them is not indifferent." He also outlined its political perspectives, suggesting the use of this power not as a factor of domination, but "to the advantage of our dignity"; David Pierre Giottino Humbert de Superville, Essai sur les signes inconditionnels dans l'art (Leyden: CC. Van der Hoek, 1827-32), 2, 28-32.

27. Boutmy, Philosophie de l'architecture en Grèce, 8.

28. Neil McWilliam, Dreams of Happiness: Social Art and the French Left 1830-1850. Princeton: Princeton University Press, 1993.

29. César Daly, "Le monument de Juillet considéré comme œuvre d'art," Revue générale de l'architecture et des travaux publics 1 (1840): col. 751.

30. César Daly, "Du symbolisme dans l'architecture," Revue générale de l'architecture et des travaux publics 7 (1847): col. 58.

31. Ibid.

32. César Daly, "Introduction," Revue générale de l'architecture et des travaux publics 25 (1867): col. 5.

33. Marc Saboya, Presse et architecture au XIX siècle. César Daly et la Revue générale de l'architecture et des travaux publics (Paris: Picard, 1991).

34. César Daly, "Conférence sur les Hautes-Études en architecture," La Semaine des constructeurs 14 (1889), 3: 25-8; 4: 37-41.

35. Édouard Lagout, L'équation du Beau: $B={ }^{ \pm m}\left(1 \times 3^{ \pm n} x 5^{ \pm p}\right)$. Loi des sensations agréables. Formule pratique pour la musique et les arts $d u$ dessin (Paris: Librairies scolaires, 1873).

36. Auguste Choisy, Histoire de l'architecture, 2 vols. (Paris: Gauthier-Villars, 1899), 404-9.

37. Émile Burnouf, "Explication des courbes dans les édifices doriques grecs," Revue générale de l'architecture et des travaux publics 32 (1875): 145-53.

38. Nina Rosenblatt, "Empathy and Anaesthesia: On the Origins of a French Machine Aesthetics,” Grey Room 2 (2001): 79-97.

39. Georges Guéroult, "Du rôle du mouvement des yeux dans les émotions esthétiques," Gazette des Beaux-arts (1881) 23: 536-42; 24: 82-90. In 1881, Georges Guéroult’s essays 
on the "Role of Movement in Aesthetic Emotions" was published at one and the same time in Revue philosophique and in Gazette des beaux-arts. Guéroult was the French translator of Hermann von Helmholtz.

40. Souriau, Paul. L'esthétique du mouvement. Paris: Alcan, 1889.

41. Crary, Jonathan. Suspensions of Perception: Attention, Spectacle and Modern Culture. Cambridge, MA: MIT Press, 2001.

42. Guyau, Jean-Marie. L'art au point de vue sociologique. Paris: Alcan, 1889.

\section{Bibliography}

Barbillon, Claire. “L'esthétique pratique de Charles Blanc.” In Charles Blanc, Grammaire des arts $d u$ dessin, 15-33. Paris: Ensba, 2000.

Blanc, Charles. Grammaire des arts du dessin. Paris: École nationale supérieure des beauxarts, 2000 [1st ed. Paris: J. Renouard, 1867].

Boutmy, Émile. Philosophie de l'architecture en Grèce. Paris: Germer Baillière, 1870.

Burnouf, Émile. "Explication des courbes dans les édifices doriques grecs." Revue générale de l'architecture et des travaux publics 32 (1875): 145-53.

Choisy, Auguste. Histoire de l'architecture. 2 vols. Paris: Gauthier-Villars, 1899.

Crary, Jonathan. Suspensions of Perception: Attention, Spectacle and Modern Culture. Cambridge, MA: MIT Press, 2001.

Daly, César. "Le monument de Juillet considéré comme ouvre d'art." Revue générale de l'architecture et des travaux publics 1 (1840): cols. 746-59.

"Du symbolisme dans l'architecture." Revue générale de l'architecture et des travaux publics 7 (1847): cols. 49-64.

"Introduction." Revue générale de l'architecture et des travaux publics 25 (1867): cols. $1-8$.

"Conférence sur les Hautes-Études en architecture." La Semaine des constructeurs 14 (1889), 3: 25-8; 4: 37-41.

Décultot, Élisabeth, ed. Revue de métaphysique et de morale: "Esthétique." Histoire d'un transfert franco-allemand. Vol. 2. Paris: Presses universitaires de France, 2002.

Espérandieu, Henry. "Le sentiment et l'architecture: De la forme et de la coloration des édifices." Revue générale de l'architecture et des travaux publics 29 (1872): cols. 12-18, $51-5,107-10$.

Guéroult, Georges. "Du rôle du mouvement des yeux dans les émotions esthétiques." Gazette des Beaux-arts 23 (1881): 536-42; 24 (1881): 82-90.

Guyau, Jean-Marie. L'art au point de vue sociologique. Paris: Alcan, 1889.

Humbert de Superville, David Pierre Giottino. Essai sur les signes inconditionnels dans l'art. Leyden: CC. Van der Hoek, 1827-32.

Jouffroy, Théodore. Cours d'esthétique. Paris: Hachette, 1843.

Lipps, Theodor. Raumaesthetik und geometrisch-optische Taüschungen. Leipzig: J. A. Barth, 1897.

Lagout, Édouard. L'équation $d u$ Beau: $B={ }^{ \pm m}\left(1 \times 3^{ \pm n} x 5^{ \pm p}\right)$. Loi des sensations agréables. Formule pratique pour la musique et les arts $d u$ dessin. Paris: Librairies scolaires, 1873. 


\section{6}

Psychology, Aesthetic, and Ornament

Lévêque, Charles. La science du beau étudiée dans ses principes, dans ses applications et son histoire. 2 vols. Paris: Durand, 1861. 2nd ed. 1872.

Mallgrave, Harry Francis and Eleftherios Ikonomou. Empathy, Form and Space: Problems in German Aesthetics, 1873-1893. Santa Monica: Getty Research Institute, 1994.

McWilliam, Neil. Dreams of Happiness: Social Art and the French Left 1830-1850. Princeton: Princeton University Press, 1993.

Rosenblatt, Nina. "Empathy and Anaesthesia: On the Origins of a French Machine Aesthetics." Grey Room 2 (2001): 79-97.

Rousseau, Pascal. "Un langage universel: L'esthétique scientifique aux origines de l'abstraction." In Aux origines de l'abstraction 1800-1914, edited by Serge Lemoine and Pascal Rousseau, 19-33. Paris: RMN, 2003.

Saboya, Marc. Presse et architecture au XIX siècle: César Daly et la Revue générale de l'architecture et des travaux publics. Paris: Picard, 1991.

Souriau, Paul. L'esthétique du mouvement. Paris: Alcan, 1889.

Stafford, Barbara Maria. Symbol and Myth: Humbert de Superville's Essay on Absolute Signs in Art. Cranbury: University of Delaware Press, 1979.

Thibault, Estelle. La géométrie des émotions: Les esthétiques scientifiques de l'architecture en France, 1860-1950. Wavre: Mardaga, 2010.

Van Zanten, David. Designing Paris: The Architecture of Duban, Labrouste, Duc and Vaudoyer. Cambridge, MA, and London: MIT Press, 1987.

Wölfflin, Heinrich. Prolegomena zu einer Psychologie der Architektur. Munich: Kgl. Hof- \& Universitäts-Buchdrückerei, 1886. 